\title{
The Impact of an Apology and Explanation on Interactional Justice in Higher Education Institutions
}

\section{Steven Kayambazinthu Msosa}

\author{
Department of Marketing, \\ Faculty of Management Sciences, \\ Mangosuthu University of Technology, \\ South Africa

\section{Courage Mlambo} \\ Department of Public Administration and Economics, \\ Faculty of Management Sciences, \\ Mangosuthu University of Technology, \\ South Africa
}

DOI: https://doi.org/10.36941/jesr-2020-0o7o

\begin{abstract}
Recently, students have been very vocal against poor services being offered by higher education institutions. These services range from lectures, registration, classroom management, examinations, transport, library services, housing or residence to the cafeteria. There is a perception that higher education institutions are not doing enough to address the challenges students are encountering even when such grievances or concerns are raised. Therefore, this study analysed the impact of an apology and explanation on interactional justice with respect to both academic and non-academic services. In addition, students' perceptions of an apology, explanation and interactional justice were evaluated. Respondents were selected from a purposive sample of 430 full-time students drawn across three public higher education institutions and data were collected using a self-administered quantitative questionnaire. Data were analysed using the SPSS and Smart PLS3. The findings of this study showed that both an explanation and an apology have a positive and significant impact on interactional justice in higher education institutions. The results also showed that students were largely satisfied with the explanation given than their perception of an apology and interactional justice. This study underpins the need for institutional managers to foster interaction between the institution and aggrieved students. Higher education institutions should offer an apology and explanation if necessary to pacify any animosity that may arise as a result of a poorly delivered service.
\end{abstract}

Keywords: Students, higher education institutions, service failure, apology, explanation, interactional justice

\section{Introduction}

In recent times, students from higher education institutions have been very vocal against the state of service delivery at various institutions. They have a legitimate expectation that institutions and their employees will offer quality service that is devoid of errors. Their understanding of quality in the higher education sector is very complex and multi-faceted. This is so because the perception of 
students on the quality of the lecturing process and other services offered by the institutions varies from one student to another (Elassy, 2015). Currently, the higher education sector is perforated with different problems that affect the operations at various institutions. However, the problems in the sector are not the same across the board. They are unique to different regions, countries, and institutions of higher learning. In Africa, the higher education sector is characterised by staff shortages, inadequate funding, inadequate facilities and infrastructure, poor quality, irrelevant teaching, research problems and failure to address issues of equitable access (Yizengaw, 2008).

Another school of thought suggests that in the developing world, higher education institutions encounter different problems such as lack of accommodation, inadequate experts in sciences, limited classroom space, lack of laboratories, poorly stocked libraries and poor funding. These problems are further exacerbated by large student intakes which are beyond institutional capacity in terms of facilities and staff. In addition, student funding in sub-Saharan Africa is also a matter of concern among students. For example, students from poor families in Nigeria resort to working on cassava farms to raise money to finance their studies and living expenses. In some cases, female students are involved in moonlighting and commercial sex as a way of raising money for their education (Peretomode \& Ugbomeh, 2013). Echoing these sentiments, the Asian Development Bank (2011) has observed that the higher education sector is struggling to meet the needs of students due to the increase in enrolment.The drawback is that despite the increase in enrolment, most institutions don't have the financial muscle to sustain the provision of quality service. In addition, universities across Asia are not internally efficient and this makes it difficult to achieve the set faculty and institutional objectives. This is further compounded by high student-lecturer ratio, unfavourable employment conditions, archaic systems of management and poor maintenance of facilities.

The World Bank (2000) argues that the problems crippling the higher education sector in the African continent are emanating from institutional failure to recruit well-qualified staff members. This problem is also prevalent in top ranked universities such that academics are leaving the profession for alternative occupations and as a result, the quality of education is compromised. Needless to say, all the problems higher education institutions encounter have a direct impact on the quality of the campus life of one of its important constituents which are students. Thus, how institutions deal or resolve challenges students encounter as a result of institutional failure to provide quality services is very critical in ensuring that there is fairness and that ultimately, the expectations of students are met.

\section{Literature Review}

Service failure in the higher education sector occurs when there is a deviation from the expected or set standards, norms, and practices among the different types and attributes of quality in higher education institutions. There are three types of quality in the higher education sector, namely academic, administrative and facilities quality. Thus, academic service quality includes the quality of lectures, availability of lecturers, intellectual ability, lecturer's expertise on the subject and the lecturer's relationship with the students. Administrative service quality encompasses the effectiveness in dealing with student queries, the process of admission and the entire process of providing education services to students. Facilities service quality includes the state of facilities such as the library, transport systems, cafeteria, student counselling, seminars and workshops (Sultan \& Wong, 2013). The learning process in institutions of higher learning is multifaceted and can be through the delivery of lessons or lectures, advising, counselling and supervision of students' projects. Students receive these services as customers of the institutions. Thus, each learning experience is unique and is assessed based on the expectation of the students. Students' expectations vary and are determined by the quality of the engagement and the outcome of the learning process. The dilemma for higher education institutions is whether the service delivered by its employees has met or exceeded the needs and expectations of the students (Yeo \& Li, 2014). 


\subsection{Apology}

Service failure is inevitable. Thus, when the services delivered by higher education institutions or their employees have failed or not met the expectations of students, steps must be undertaken to address the service failure. One way of resolving such grievances, is to acknowledge the service failure through an apology. Normally, individuals expect an apology to be issued by employees of an organisation when the service delivered is mediocre or is of poor quality. The implication is that sometimes an apology may not make sense to a student when offered by an employee of the university, but the reality is that the absence of an apology may leave an indelible negative mark on the employee or the corporate image of the institution (Sumaco \& Hussain, 2011).

A good apology by employees of higher education institutions should have three important elements, namely timing, intensity, and empathy. Empathy implies that employees of higher education institutions should show remorse and be sympathetic to students, whereas timing means that employees should immediately offer an apology as soon as a complaint is registered by the student (Roschk \& Kaiser, 2013). Similarly, Ebesu Hubbard, Hendrickson, Fehrenbach and Sur (2013) have noted that the service recovery process is effective when the apology is sincere and timely. This might assist the service provider in effectively communicating the expression of regret and remorsefulness (if in the wrong). Intensity means that the apology by employees of higher education institutions should contain words such as 'sorry'. Thus, an intense apology can assist higher education institutions to regain equilibrium in their relationship with students than when a moderate apology is offered (Roschk \& Kaiser, 2013).

\subsection{Explanation}

Students who are dissatisfied with the service offered or delivered by higher education institutions expect that an explanation will be provided as to why the service failure has occurred in the first place. Therefore, it is important for institutions or their employees to explain the reason behind the service failure and the measures being undertaken to deal with the problem. For this to materialise, institutions must engage employees capable of dealing with students in a friendly and effective way (Fierro, Pineda, Benitez, and Carrasco, 2011).

Students expect institutional employees to show empathy to their predicament and take steps to address the service failure. The reality is that students are aware that in some cases, they may not be provided with a resolution that is satisfactory. However, a good explanation may help the employee and the institution to restore their image and placate students' frustration (Casado, Nicolau \& Mas, 2008). Conversely, Iglesias, Varela-Neira, and Vazquez-Casielles (2015) have noted that an explanation may not be an effective service recovery strategy in cases of high intentionality. Thus, students' distrust of higher education institutional managers and employees may provoke them not to accept any service recovery efforts or commitments that are only based on words without tangible action. In such scenarios, the provision of tangible service recovery initiatives may signify the institution's willingness and intention to address the problem and not just a mere act of hypocrisy and disdain. In some cases, it may not be possible to manage students' perception of intentionality. However, it may be beneficial to institutions if they can provide an appropriate explanation for the complaints registered with the institution.

\subsection{Interactional Justice}

Interactional justice is the extent to which students perceive fairness in the conduct of university employees through different avenues of communication during service recovery. As part of the interaction, employees of the university should manage the students' emotional well-being and experiences immediately after encountering service failure (Ibrahim and Abdallahamed, 2014). Thus, service recovery efforts can only be effective if higher education institutions can ensure that fair 
interaction and outcome are provided. A fair interaction is one that includes an apology that is sincere and an explanation of what had prompted the service failure to occur and an undertaking to address the service failure (Mohamad, Abdullah \& Mokhlis, 2011). Assefa (2014) avers that interaction plays a critical role during service failure and recovery. Thus, students expect to interact with university employees who are concerned with their situation and are eager to provide a plausible explanation as to what had triggered the service failure. Similarly, Komunda (2013) believe that students who are unhappy with campus services expect a good explanation from institutional management and employees to restore their joy. In addition, students expect the institution to take responsibility for a poorly delivered service. Therefore, providing students with a speedy recovery initiative is critical and if such cannot be provided, the institution must apprise the students with updated information or an explanation of the recovery efforts that have been put in place to address the service failure incident.

Previous studies on service recovery strategies such as the impact of an explanation and apology on interactional justice have largely been in sectors that have low exit barriers such as the mobile sector (Mostafa, Lages, Shabbir \& Thwaites, 2015). There is a dearth of research on the impact of service recovery strategies (apology and explanation) on interactional justice in sectors with high exit barriers such as the higher education sector. This is against the backdrop of many service failure incidents that have been reported at various higher education institutions. Therefore, the aim of this study was to evaluate the impact of an apology and explanation on interactional justice. To achieve this aim, the following objectives were derived:

1. Students' perception of an apology in higher education institutions.

2. Students' perception of an explanation in higher education institutions.

3. Students' perception of interactional justice in higher education institutions.

4. The impact of an apology on interactional justice in higher education institutions.

5. The impact of an explanation on interactional justice in higher education institutions.

\section{Research Methodology}

\subsection{Research Design and Sample}

This study adopted a descriptive, quantitative and cross-sectional approach. Descriptive research is used to describe the characteristics of a phenomenon and is normally used to analyse quantitative data (Nassaji, 2015). Data for this research were collected from a purposive sample of 430 full-time students across three public higher education institutions in South Africa using a self-administered questionnaire. Specifically, this study was conducted in the province of KwaZulu-Natal. The students in this study were carefully selected using a purposive sampling approach because of the qualities or characteristics that they possess (Sharma, 2017). Thus, only students that have encountered service failure when accessing both academic and non-academic services participated in the study because of the absence of a sampling frame.

\subsection{Research Instruments and Procedures}

The questionnaire items for the three variables used in this study were adapted from previous studies. For instance, an apology and explanation (Mostafa, Lages \& Saaksjarvi, 2014; Ramadan, 2012) and interactional justice (Ramadan, 2012) as shown in Table 1. A five-point Likert scale with predetermined options ranging from strongly disagree signifying scale number 1,2 representing disagree, 3 representing neutral, 4 representing agree to strongly agree signifying scale number 5 were adopted in this study to enable university students to gauge their feelings of the impact of an apology and explanation on interactional justice. For purposes of evaluation of the results, scale numbers 1 and 2 were collapsed into disagree whereas scale numbers 4 and 5 were collapsed into agree while maintaining 3 representing neutral as shown in Tables 2, 3 and 4 . In this study, students were 
requested to evaluate their perception of an apology, explanation and interactional justice based on each item presented in the questionnaire.

\subsection{Data Analysis}

Data for descriptive statistics were analysed by means of the SPSS whereas inferential statistics were analysed by means of the Smart PLS3. Descriptive statistics were analysed using frequencies and percentages presented in a tabular form. A confirmatory factor analysis was undertaken to ascertain the validity of the research instrument and the findings in Table 1 show all items loaded perfectly above the acceptable cut off point of 0.4 (Wiid \& Diggines, 2015). Similarly, the internal consistency of the questionnaire was ascertained by measuring reliability through the Cronbach alpha and the cut-off point was 0.7 (Tavakol \& Dennick, 2011). As shown in Table 1, all variables had Cronbach alpha scores above the acceptable threshold (Apology $=0.904$; Explanation $=0.900$ and Interactional justice $=0.931$ ). Discriminant validity was assessed using the average variance extracted (AVE) and as shown in Table 1, the AVE scores (apology $=0,702$; Explanation $=0.750$ and interactional justice $=0.693$ were above the 0.5 mark which is the acceptable cut-off point (Fornell \& Larcker, 1981).

Table 1: Reliability and Validity

\begin{tabular}{|c|c|c|c|c|}
\hline Factor & Item/question & $\begin{array}{l}\text { Factor } \\
\text { loading }\end{array}$ & $\begin{array}{l}\text { Cronbach } \\
\text { alpha }\end{array}$ & $\begin{array}{l}\text { Average } \\
\text { variance } \\
\text { extracted }\end{array}$ \\
\hline $\begin{array}{l}\text { Apology } \\
\text { (Mostafa et al., 2014; } \\
\text { Ramadan, 2012) }\end{array}$ & $\begin{array}{l}\text { Employees were sorry for the inconvenience } \\
\text { Employees apologised for what happened } \\
\text { Employees expressed regret for the mistake } \\
\text { Employees offered additional benefits }\end{array}$ & $\begin{array}{l}0.821 \\
0.848 \\
0.832 \\
0.851 \\
\end{array}$ & 0.904 & 0.702 \\
\hline $\begin{array}{l}\text { Explanation } \\
\text { (Mostafa et al., 2014; } \\
\text { Ramadan, 2012) } \\
\end{array}$ & $\begin{array}{l}\text { Employees explained what caused the problem } \\
\text { Employees explained what might have gone wrong } \\
\text { Employees provided a convincing explanation }\end{array}$ & $\begin{array}{l}0.825 \\
0.823 \\
0.944 \\
\end{array}$ & 0.900 & $0.75^{\circ}$ \\
\hline $\begin{array}{l}\text { Interactional Justice } \\
\text { (Ramadan, 2012) }\end{array}$ & $\begin{array}{l}\text { Employees gave confidence } \\
\text { Employees had knowledge } \\
\text { Employees gave individual attention } \\
\text { Employees put in the proper effort } \\
\text { Employee communication was appropriate } \\
\text { Employees gave the courtesy I was due }\end{array}$ & $\begin{array}{l}0.798 \\
0.821 \\
0.815 \\
0.853 \\
0.839 \\
0.866\end{array}$ & 0.931 & 0.693 \\
\hline
\end{tabular}

\section{Results}

\subsection{Explanation}

Students were asked whether the university had explained the factors that might have caused the problem. As depicted in Table 2, 43.7 percent (188) of the students agree, followed by 30.7 percent (132) who disagree and 25.6 percent (110) who were neutral. Furthermore, 41.4 percent (178) of the students agree that the university explained what might have gone wrong, followed by 30.9 percent (133) who agree and 27.7 percent (119) who were neutral. Table 2 further shows that 35.6 percent (153) of the students disagree that the university provided a convincing explanation for the reported problem, followed by 34.9 percent (150) who agree and 30.9 percent (119) who were neutral. 
Table 2: Descriptive analysis of students' perception of an explanation

\begin{tabular}{lcccccccc}
\hline Explanation & \multicolumn{2}{c}{ Disagree } & \multicolumn{2}{c}{ Neutral } & \multicolumn{2}{c}{ Agree } & \multicolumn{2}{c}{ Total } \\
\hline & $\mathrm{n}$ & $\%$ & $\mathrm{n}$ & $\%$ & $\mathrm{n}$ & $\%$ & $\mathrm{n}$ & $\%$ \\
Employees explained what caused the problem & 132 & $30.7 \%$ & 110 & $25.6 \%$ & 188 & $43.7 \%$ & 430 & $100 \%$ \\
Employees explained what might have gone wrong & 133 & $30.9 \%$ & 119 & $27.7 \%$ & 178 & $41.4 \%$ & 430 & $100 \%$ \\
Employees provided a convincing explanation & 153 & $35.6 \%$ & 127 & $29.5 \%$ & 150 & $34.9 \%$ & 430 & $100 \%$ \\
\hline
\end{tabular}

\subsection{Apology}

Table 3 shows that 47 percent (202) of the students disagree that the university or employees were sorry for the inconvenience caused, followed by 30.4 percent (131) who agree and 22.6 percent (97) who were neutral. Students were asked whether the university apologised to them for what had happened. The findings as indicated in Table 3 illustrate that 48.6 percent (209) of the students disagree followed by 27.7 percent (119) and 23.7 percent (102) who were neutral. Furthermore, 47 percent (202) of the students disagree that the university or its employees expressed regret for the mistake that had occurred, followed by 27.2 percent (93) who were neutral and 25.8 percent (111) who agree. Students were asked whether they had received additional benefits as a token for the mistake or service failure by the university. The results as depicted in Table 3 show that 57 percent (245) of the students disagree followed by 22.3 percent (96) who were neutral and 20.7 percent (89) who agree.

Table 3: Descriptive analysis of students' perception of an apology

\begin{tabular}{lccccccccc}
\hline Apology & \multicolumn{2}{c}{ Disagree } & \multicolumn{2}{c}{ Neutral } & \multicolumn{2}{c}{ Agree } & \multicolumn{3}{c}{ Total } \\
\hline & $\mathrm{n}$ & $\%$ & $\mathrm{n}$ & $\%$ & $\mathrm{n}$ & $\%$ & $\mathrm{n}$ & $\%$ \\
Employees were sorry for the inconvenience & 202 & $47 \%$ & 97 & $22.6 \%$ & 131 & $30.4 \%$ & 40 & $100 \%$ \\
Employees apologised for what happened & 209 & $48.6 \%$ & 102 & $23.7 \%$ & 119 & $27.7 \%$ & 430 & $100 \%$ \\
Employees expressed regret for the mistake & 202 & $47 \%$ & 93 & $27.2 \%$ & 111 & $25.8 \%$ & 430 & $100 \%$ \\
Employees offered additional benefits & 245 & $57 \%$ & 96 & $22.3 \%$ & 89 & $20.7 \%$ & 430 & $100 \%$ \\
\hline
\end{tabular}

\subsection{Interactional Justice}

As shown in Table 4, 37.4 percent (161) of the students disagree that the behaviour of university employees gave them the confidence to deal with the employees, followed by 33.5 percent (144) who agree and 29.1 percent (125) who were neutral. İn addition, 40.7 percent (175) of the students agree that the university employees had the requisite knowledge to respond to their questions, followed by 31.2 percent (134) who were neutral and 28.1 percent (121) who disagree. Similarly, 38.4 percent (165) of the students disagree that the university employees gave them individual attention, followed by 36.5 percent (157) who agree and 25.1 percent (108) who were neutral. The results further show that 35.6 percent (155) of the students disagree that university employees had put proper effort into resolving their problems, followed by 32.6 percent (140) who were neutral and 31.9 percent (137) who agree. İn addition, 41.2 percent (177) of the students agree that the university employee communication with them was appropriate, followed by 31.2 percent (134) who disagree and 27.7 percent (119) who were neutral. As presented in Table 4, the results show that 35 percent (151) of the students agree that the employee gave the courtesy that was due to them, followed by 34.4 (148) who disagree and 30.5 percent (131) who were neutral. 
Table 4: Descriptive analysis of students perception of interactional justice

\begin{tabular}{|c|c|c|c|c|c|c|c|c|}
\hline \multirow[t]{2}{*}{ Interactional Justice } & \multicolumn{2}{|c|}{ Disagree } & \multicolumn{2}{|c|}{ Neutral } & \multicolumn{2}{|c|}{ Agree } & \multicolumn{2}{|c|}{ Total } \\
\hline & $\mathrm{n}$ & $\%$ & $\mathrm{n}$ & $\%$ & $\mathrm{n}$ & $\%$ & $\mathrm{n}$ & $\%$ \\
\hline e confidence & 161 & $37.4 \%$ & 125 & $29.1 \%$ & 144 & $33.5 \%$ & 430 & $100 \%$ \\
\hline Employees had knowledge & 121 & $28.1 \%$ & 134 & $31.2 \%$ & 175 & $40.7 \%$ & 430 & $100 \%$ \\
\hline Employees gave individual atter & 165 & $38.4 \%$ & 108 & $25.1 \%$ & 157 & $36.5 \%$ & 430 & $100 \%$ \\
\hline Employees put in proper effort & 153 & $35.6 \%$ & 140 & $32.6 \%$ & 137 & $31.9 \%$ & 430 & $100 \%$ \\
\hline Employees communication was & 134 & $31.2 \%$ & 119 & $27 \cdot 7 \%$ & 177 & $41.2 \%$ & 430 & $100 \%$ \\
\hline Employees gave the courtesy I was due & 148 & $34.4 \%$ & 131 & $30.5 \%$ & 151 & $35.1 \%$ & 430 & $100 \%$ \\
\hline
\end{tabular}

\subsection{Impact of an apology and explanation on interactional justice}

When determining a correlation coefficient, it is important to conduct tests for significance. This helps to evaluate the relationship between variables. Thus, in order to determine the correlation coefficient for statistical significance, there is a need to ascertain the true correlation coefficient that can be easily observed if all population values were obtained. The true correlation coefficient is represented by a symbol $p$ (Wiid \& Diggines, 2015). This study evaluated the impact of an apology on interactional justice in higher education institutions. Table 5 shows that an apology has a significant and positive impact on interactional justice $(\beta=0.407, \mathrm{t}$-value $=7.522, p=0.000)$. Similarly, further investigations were conducted to analyse the impact of an explanation on interactional justice. As shown in Table 5 , the findings indicate that an apology has a positive and significant impact on interactional justice $(\beta=0.437$, t-value $=8.0280 p=0.000)$.

Table 5: Impact of an explanation and apology on interactional justice

\begin{tabular}{lccccc}
\hline Factors & $\begin{array}{c}\text { Original } \\
\text { Sample }(\mathbf{O})\end{array}$ & $\begin{array}{c}\text { Sample } \\
\text { Mean (M) }\end{array}$ & $\begin{array}{c}\text { Standard } \\
\text { Deviation (STDEV) }\end{array}$ & $\begin{array}{c}\text { T-Statistics } \\
(\mid \mathbf{O} / \text { STDEV } \mid)\end{array}$ & P-Values \\
\hline Apology -> Interactional justice & 0.437 & 0.435 & 0.054 & 8.028 & 0.000 \\
Explanation - Interactional justice & 0.407 & 0.409 & 0.054 & 7.522 & 0.000 \\
\hline Note: SE (standard error), ns (not significant), ${ }^{*} p<0.05,{ }^{* *} p<0.01,{ }^{* * *} p<0.001$ (two-tailed t-tests)
\end{tabular}

Table 6 shows that all the relationships or paths that were subject to an investigation in this study viz. apology $\rightarrow$ interactional justice and explanation $\rightarrow$ interactional justice were positive and significant hence the final results were supported.

Table 6: Summary of the results of the impact of an explanation and apology on interactional justice

\begin{tabular}{lcccc}
\hline Factors & $\begin{array}{c}\text { Original } \\
\text { Sample }(\mathbf{O})\end{array}$ & $\begin{array}{c}\text { T-Statistics } \\
(\mid \mathbf{O} / \text { STDEV } \mid)\end{array}$ & P-Values & Result \\
\hline Apology $->$ Interactional justice & 0.437 & 8.028 & $0.000^{* * *}$ & $\begin{array}{c}\text { Supported } \\
\text { Explanation }->\text { Interactional justice }\end{array}$ \\
\hline Note: SE (standard error), ns (not significant), ${ }^{*} p<0.05,{ }^{* *} p<0.01,{ }^{* * *} p<0.001$ (two-tailed t-tests) &
\end{tabular}

\section{Discussion}

This study analysed the impact of an explanation and apology on interactional justice in higher education institutions. In addition, students' perceptions of an explanation, apology, and interactional justice were evaluated. Firstly, the reliability and validity of the study were conducted to ascertain the suitability of the research instrument. The results showed that both reliability and 
validity scores for the three variables (apology, explanation and interactional justice) were acceptable. In addition, the study conducted a descriptive analysis of an apology and explanation) based on students' perceptions. The majority of the students were satisfied with the explanation given with respect to what caused the problem and what might have gone wrong. Furthermore, the students felt that the explanation provided by the institutions was not convincing. With respect to an apology, the majority of the students indicated that university employees did not apologise, express regret and offer additional benefits for what had happened. Extant research has noted that institutions need to understand that while it may be difficult to entirely prevent service failure on campus, they have several options for managing the service failure by adapting the communication strategy to students. This implies that where service failure can be attributed to external factors, higher education institutions must clearly explain that the cause of the service failure was due to external factors. Thus, such an explanation can assist in mitigating against the students drawing premature conclusions on the controllability of the situation (von Aswege, Kemper \& Brettel, 2018).

Students' perception of interactional justice was also evaluated and the findings showed that most of the students felt that the university and its employees did not fully provide interactional justice during their service recovery encounter. However, there was also an indication that students were satisfied with certain aspects of interactional justice such as employee knowledge, communication and the courtesy that was due to them. Ozuem, Patel, Howell, and Lancaster (2017) have observed that institutions must provide a conducive environment where students perceive that their treatment is fair and that efforts are being undertaken to address the problem. Thus, as an element of interactional justice, communication with students regarding the service failure incident and all service recovery efforts should be prioritised. Ultimately, the nature of communication should be able to provide evidence of equitable solutions and justice to ensure students' recovery satisfaction.

In addition to descriptive statistics, this study also analysed the impact of an explanation on interactional justice using inferential statistics. The results showed a positive and significant impact of an explanation on interactional justice. The findings in the current study are similar to another study, which concluded that an explanation has a positive and significant impact on interactional justice (Mostafa et al., 2015). Furthermore, the impact of an apology on interactional justice was determined and the results showed a positive and significant impact of an apology on interactional justice. In the same vein, extant research has found that an apology has a positive and significant impact on interactional justice (Shin, Casidy \& Mattila, 2018). Similarly, other scholars have also found that an apology has a significant effect on interactional justice (Choi \& Choi, 2014).

\section{Conclusion and Recommendations}

Based on the findings of this research, higher education institutional managers should encourage good interpersonal communication among its employees when interacting with students. Skills such as listening, empathy and emotional intelligence can be achieved through training and workshops. İn addition, members of staff should be advised to provide a proper explanation whenever a service failure incident is reported. Such an explanation can assist students to understand what triggered the service failure and also the initiative being undertaken to address the service failure. It is further recommended that higher education institutional employees should familiarise themselves with internal processes and the services offered by the universities, such as information relating to registration, tuition fees, residence, and the library. Thus, product or service knowledge is a prerequisite for quality service delivery. İn this regard, the human resources department and the faculty managers should provide in-house training and orientation to enable employees to familiarise themselves with key institutional processes and services.

Institutional managers should also encourage employees to show emphathy when interacting with students. As one way of showing empathy, employees should not be seen to be justifying or legitimising the service failure incident, even when the student is at fault or entirely to blame for the 
service failure. It is the responsibility of employees to make students feel welcome and at ease when dealing with their problems. Furthermore, employees of higher education institutions should be encouraged to use the right tone when providing an explanation or an apology. An apology is regarded as the cheapest means of addressing service failure because there is no cost or expense attached to offering an apology whenever the institution has failed to offer a service that meets the expectation of students. Therefore, the management of higher education institutions should encourage employees to offer an apology as a service recovery strategy before trying other options as soon as a student has reported a service failure incident. This can assist in pacifying students' emotions such as anger and rage. Furthermore, a timely apology is critical in demonstrating fairness and a sense of responsibility by the institution or employee. Ultimately, not every service recovery strategy is ideal for a service failure. The onus is on institutional managers and university employees to gauge if the service recovery strategy deployed is ideal to resolve the reported service failure incident. For instance, an apology may not be enough where wrong marks have been allocated to a student. The lecturer or employee must restore the students to the rightful position by giving him the correct marks.

\section{Contribution and Limitations}

This study has contributed to the literature on interactional justice in the higher education sector. İn addition, it is one of the pioneering studies to evaluate the impact of an apology and explanation on interactional justice in the higher education sector. Unlike other studies that have focussed their research in a commercial or profit-driven sector, this study makes a groundbreaking investigation on the use of an explanation and apology to address service failure incidents that students encounter in higher education institutions. Future studies should focus on the impact of service recovery strategies on other dimensions of justice in the higher education sector. İn addition, further research can also be extended to basic education and evaluate how teachers resolve challenges that students encounter. The limitation of this study is that it was based on a small sample size and conducted in three public higher education institutions in the province of Kwazulu Natal. As such, the findings of this study cannot be generalised to the remaining 23 public higher education institutions in South Africa. However, these findings may assist other higher education institutions in benchmarking their service delivery and recovery performance in order to devise better ways of addressing student problems.

\section{References}

Assefa, E.S. (2014). The effects of justice oriented service recovery on customer satisfaction and loyalty in retail banks in Ethiopia. Emerging Markets Journal, 4(1), 48-58.

Asian Development Bank. (2011). Higher education across Asia: an overview of issues and strategies. Mandaluyong city, Philippines. Available online: https://www.adb.org/sites/default/files/publication/29407/highereducation-across asia.pdf. (Accessed: 4 October 2018).

Casado, A.B., Nicolau, J.L., \& Ruiz, F.M. (2008). The negative effects of failed service recoveries (No. 2008-07). Instituto Valenciano de Investigaciones Económicas, SA (IVIE).

Choi, B. J., \& Choi, B. J. (2014). The effects of perceived service recovery justice on customer affection, loyalty, and word-of-mouth. European Journal of Marketing, 48 (1/2), 108-131.

Ebesu Hubbard, A.S., Hendrickson, B., Fehrenbach, K.S., \& Sur, J.(2013). Effects of timing and sincerity of an apology on satisfaction and changes in negative feelings during conflicts. Western Journal of Communication, 77(3), 305-322.

Elassy, N. (2015). The concepts of quality, quality assurance and quality enhancement. Quality Assurance in Education, 23(3), 250-261.

Fierro, J.J.C., Pineda, J.M.B. Benítez, R.R., \& Carrasco, R.V. (2011). Does the customer's educational level moderate service recovery processes?. International Journal of Business and Social Science, 2(21), 59-71.

Fornell, C., \& Larcker, D.F. (1981). Evaluating structural equation models with unobservable variables and measurement error. Journal of Marketing Research, 18(1), 39-50. 
Ibrahim, M., \& Abdallahamed, S.(2014). Service recovery and customer satisfaction: A case of Ugandan Telecom. European Journal of Business and Management, 6(4), 197-209.

Iglesias, V., Varela-Neira, C., \& Vázquez-Casielles, R. (2015). Why didn't it work out? The effects of attributions on the efficacy of recovery strategies. Journal of Service Theory and Practice, 25(6), 700-724.

Komunda, M.B. (2013). Customer complaints behaviour, service recovery and behavioural intentions: A Literature review. International Journal of Business and Behavioural Success, 3(7), 1-29.

Mohamad, M., Abdullah, A.R., \& Mokhlis, S. (2011). Examining the Influence of Service Recovery Satisfaction on Destination Loyalty: A Structural Equation Modelling. Journal of Sustainable Development, 4(6), 3.

Mostafa, R.B., Lages, C.R., Shabbir, H.A., \& Thwaites, D. (2015). Corporate image: A service recovery perspective. Journal of Service Research, 18(4), 468-483.

Mostafa, R., R. Lages, C., \& Sääksjärvi, M. (2014). The CURE scale: a multidimensional measure of service recovery strategy. Journal of Services Marketing, 28(4):300-310.

Nassaji, H. 2015. Qualitative and descriptive research: Data type versus data analysis. Language Teaching Research, 19(2), 129-132.

Ozuem, W., Patel, A., Howell, K.E., \& Lancaster, G. (2017). An exploration of consumers' response to online service recovery initiatives. International Journal of Market Research, 59(1), 97-115.

Peretomode, V.F., \& Ugbomeh, A.N. (2013). Problems faced by undergraduate and diploma students and their survival strategies in Nigeria: An institutional analysis. International Journal of Educational Planning and Administration, 3(1), 25-33.

Ramadan, A.G.A. (2012). Exploring service recovery and justice theory in the Libyan airline industry. Ph.D. Thesis. University of Gloucestershire.

Roschk, H., \& Kaiser, S. (2013). The nature of an apology: An experimental study on how to apologize after a service failure. Marketing Letters, 24(3), 293-309.

Sharma, G. (2017). Pros and cons of different sampling techniques. International Journal of Applied Research, 3(7):749-752.

Shin, H., Casidy, R., \& Mattila, A.S. (2018). Service Recovery, Justice Perception, and Forgiveness: The "Other Customers" Perspectives. Services Marketing Quarterly, 39(1), 1-21.

Sultan, P., \& Wong, H.Y. (2013). Antecedents and consequences of service quality in higher education context: a qualitative research approach. Quality Assurance in Education, 21(1), 70-95.

Sumaco, F.T., \& Hussain, K. (2011). Evaluation of service recovery strategies in the hotel industry: Perspectives of the front office department. Team Journal of Hospitality and Tourism, 8(1), 44-51.

Tavakol, M., \& Dennick, R. (2011). Making sense of Cronbach's alpha. International Journal of Medical Education, 2, 53-55.

von Aswege, F., Kemper, J., \& Brettel, M. (2018). The Impact of Service Failure Controllability and Relationship Strength on Post-Complaint Consumer Behavior-An Empirical Analysis. In: Proceedings of the 51st Hawaii International Conference on System Sciences.

Wiid, J., \& Diggines, C. (2015). Marketing research. $3^{\text {rd }}$ ed. Cape Town: Juta.

World Bank. (200o). Higher education in developing countries: peril and promise. Available online: http://siteresources.worldbank.org/EDUCATION/Resources/2782001099079877269/547664-1099079956815/ peril_promise_en.pdf. (Accessed: 4 November, 2018).

Yeo, R.K., \& Li, J. (2014). Beyond SERVQUAL: the competing forces of higher education in Singapore. Total Quality Management, 25(2), 95-123.

Yizengaw, T. (2008). Challenges of higher education in Africa and lessons of experience for the Africa-US higher education collaboration initiative. National Association of State Universities and Land-Grant Colleges. Draft Working Paper 1: 1-21. 